2001

\title{
The Strange History of Adult Adoptee Access to Original Birth Records
}

Elizabeth Samuels

University of Baltimore School of Law, esamuels@ubalt.edu

Follow this and additional works at: http://scholarworks.law.ubalt.edu/all_fac

Part of the Family Law Commons, and the Juvenile Law Commons

\section{Recommended Citation}

The Strange History of Adult Adoptee Access to Original Birth Records, 5 Adoption Quarterly 63 (2001)

This Article is brought to you for free and open access by the Faculty Scholarship at ScholarWorks@University of Baltimore School of Law. It has been accepted for inclusion in All Faculty Scholarship by an authorized administrator of ScholarWorks@University of Baltimore School of Law. For more information, please contact snolan@ubalt.edu. 


\section{LEGAL INTERSECTIONS}

\section{The Strange History of Adult Adoptee Access to Original Birth Records}

Elizabeth J. Samuels, JD

When I researched the history of adult adoptees' access to original birth records, I did not find what I expected. I expected to find information that would explain why, sometime during the first half of the 20th century, it had been considered beneficial to close these records to adult adoptees. Instead I discovered that influential authorities during this period advised the states to permit adult adoptee access to birth records, while otherwise sealing court and birth records from inspection without a court order. I discovered that as late as 1960 , the laws in some 40 percent of the states still did permit adult adoptees to inspect their birth records. These discoveries led me to consider both why many states had nevertheless foreclosed access by that date and why most of the other states eventually changed their laws during the period from 1960 to 1990 , foreclosing access at the same time that a movement was developing for greater openness in adoption. ${ }^{1}$

My interest in the history of secrecy in adoption law had grown out of both my professional and my personal experiences. I had addressed adoption law issues when I taught "Child and Family Law," and I had

Elizabeth J. Samuels is Associate Professor at the University of Baltimore School of Law, Baltimore, MD.

Adoption Quarterly, Vol. 5(2) 2001

http://www haworthpressinc.com/store/product.asp?sku=J145

(c) 2001 by The Haworth Press, Inc. All rights reserved. 
earlier encountered a number of them at closer hand when my older sister surrendered a child for adoption and when I later helped facilitate their reunion. My sister had traveled overseas to England before the birth; so it was when I was living in London some 25 years later, in the mid 1980s, that I approached my neighborhood social worker to inquire how we might register my sister's willingness to provide information to or be contacted by her child. Even in England, a country in which adoption records had been open to adult adoptees for ten years, the worker's distaste for my mission was palpable. "Why," she fairly sniffed, "would my sister want to do such a thing?"'

Attitudes like the worker's, which censured breaches of adoption secrecy, were pervasive in the United States as well. At the same time, a movement for greater openness in adoption was becoming increasingly visible here. Many adult adoptees and birth parents, like my own relatives, were searching for one another and were reporting profound, life-enhancing satisfactions from either obtaining information or experiencing reunions. Their positive reports were a dramatic contrast to the negative social attitudes (see Samuels, 2001). Why, I wondered, had we enacted and maintained laws that now frustrated many of the individuals the laws were surely intended to benefit?

No detailed legal research had been done into the history of these laws, but I had taken from my reading in legal literature what seemed to be the general understanding that almost all the states had completely sealed court and birth records by about the middle of the century. It seemed, according to this understanding, that after the legal institution of adoption was established by the states-during the second half of the 19 th century and the early years of the 20th-most states proceeded in the first part of the 20th century to close court records to the public and, where amended birth records had been issued, to close original birth records as well. Then, by the middle of the century, the states also closed these records to all the individuals involved in the adoptions (see Samuels, 2001). A closer examination of the historical record indicates, however, that states closed records to the public somewhat later in the first half of the century and that many states, while they closed court records to all the individuals involved in the adoptions, initially closed birth records to birth parents, adoptive parents, and minor adoptees but preserved access for adult adoptees (Samuels, 2001).

In the late 1940 s and early 1950 s, contemporary accounts reported that most states had sealed court records completely but, typically, had sealed birth records from all persons except adult adoptees (Samuels, 2001). In fact, a significant shift in birth records policies must have been 
underway during that time because in 1960 , when the 49 states and the District of Columbia reported their laws and procedures to the federal government, 28 reported that original birth records were available only by court order. (State procedures for obtaining such orders did not require notice to or participation by birth parents.) Twenty other states, however, 40 percent of the jurisdictions, reported that birth records were available to adult adoptees upon demand, with four of the states not specifying that the adoptee must be an adult and seven also providing for access by adoptive parents. In addition to the 20 states that permitted adult adoptee access, one state provided for inspection at the state registrar's discretion or by court order, and another state provided for inspection at the discretion of the state registrar or the town clerk (National Office of Vital Statistics, 1960). Among those states that in 1960 did not permit adult adoptee access to birth records, at least a few permitted some access to court records: one provided adult adoptees access to court records, another provided adoptive parents and perhaps adult adoptees access to court records, and a third provided adoptive parents access to court records (Samuels, 2001).

Of the 20 states that permitted adult adoptee access to birth records in 1960, Alaska and Kansas have never changed their laws, and a third state, South Dakota, has effectively continued to permit adult adoptee access to birth and court records upon demand, although it has become necessary to secure a court order (Samuels, 2001). Four of the states foreclosed adult adoptee access in the $1960 \mathrm{~s},{ }^{2}$ six did so in the $1970 \mathrm{~s},{ }^{3}$ and seven did so after $1979 .{ }^{4}$ As social attitudes about secrecy in adoption evolved, it is possible that the practices of states' records custodians' did not always conform to their laws during the periods from 1960 until their laws changed, and there is some evidence that this was the case (Samuels, 2001). But the fact that such a substantial number of states had laws in 1960 permitting adult adoptee access is consistent with the expert recommendations disseminated in the years preceding that date.

Through the 1950s influential experts recommended that original birth records remain available to adult adoptees, while birth and court records otherwise be closed to all persons except upon court order. The reasons proffered for closing records were the need to protect adoptees from the potentially embarrassing disclosure of the circumstances of their birth and the need to protect adoptive families raising their children from possible interference by birth parents. There appears to be essentially no discussion in the literature about any need to protect birth 
parents, or adult adoptees themselves, from the adult adoptees acquiring information about their birth families.

The U.S. Children's Bureau was one of the most influential actors in the development of adoption law in the mid twentieth century. The Bureau in the 1940 s and 1950 s advised in its studies and reports and in articles by Bureau representatives that court and birth records should be shielded from public inspection, that birth parents and adoptive parents who do not know one another should not have access to information about one another's identity, and that original birth records should be available to adult adoptees. As one publication explained, it was desirable to issue amended birth certificates in order to spare the adoptee "the embarrassment of having a birth certificate which gives information of the circumstances of his birth" and "the embarrassment of explaining why his own name and the names of the parents are not the same as the names on this birth record" (Colby, 1941, pp. 122 \& 120). It was considered desirable to conduct placements "in such a way that the natural parents do not know where the child is" (Children's Bureau, 1955, p. 13). The child should be protected from "interference of his natural parents after he has been happily established in his adoptive home" (Morlock, 1945, p. 67). But the Bureau endorsed adult adoptee access to original birth certificates because, as one of its consultants in services for unmarried mothers wrote in 1946, "every person has a right to know who he is and who his people were" (Morlock, 1946, p. 168).

The influential private organization the Child Welfare League of America in the 1940 s and 1950 s offered the same reasons as the Children's Bureau for sealing adoption records. The League in 1959 recommended sealing original birth certificates in order "to protect individuals from possible embarrassment in revealing that they were born out of wedlock, or that one parent happened to be in an institution when the child was born" (CWLA, 1959, pp. 64-65). The League counseled its member social service agencies to protect adoptive parents by assuring them that "natural parents will not know with whom the child is placed" (CWLA, 1959, p. 31).

Similar reasons for closing adoption records were offered by the authors of articles in legal periodicals. One author explained in 1950 that in independent adoptions in which identities are seldom concealed, "adoptive parents are frequently harassed by a mother who has changed her mind and wants her child back" (Student comment, 1950, p. 724). In 1954, another author praised new legislative provisions that eliminated contact between birth and adoptive parents: "A family adopting a child released under such circumstances has the safeguard of a guarantee that 
in the future the natural parents cannot disturb their happiness by the assertion of any rights in the child" (Goldman, 1954, p. 59). An American Bar Association committee chair in 1969 described the reason for secrecy in adoption as the protection of "the adopted child and his adoptive parents from possible harassment and invasions of privacy" by birth parents (Infausto, 1969, p. 137).

Two model state laws issued by the National Conference of Commissioners on Uniform State Laws, one in 1942 and one in 1953, contained the provisions recommended by the Children's Bureau. The first Uniform Adoption Act, published in 1953, provided that adoption court records be sealed and withheld from inspection except by court order (NCCUSL, 1953, \&13[1]). Original birth records, in conformance with the provisions of the Uniform Vital Statistics Act of 1942 (NCCUSL, 1942), were to be sealed and opened only "upon the demand of the adopted person if of legal age or by an order of court" (NCCUSL, 1953, $\$ 13[2])$. However, the vital statistics act's provision for adult adoptee access was deleted without explanatory comment in the 1959 successor to the act, the Model Vital Statistics Act issued by the U.S. Public Health Service (National Office of Vital Statistics, 1959). The 1969 revision of the Uniform Adoption Act omitted altogether the earlier adoption act's provision regarding sealing birth records, also without explanatory comment (NCCUSL, 1969).

Thus, curiously, it is difficult to find through the $1960 \mathrm{~s}$ in relevant bodies of professional literature the expression of any specific reasons for closing original birth records to adult adoptees. With respect to desires of pregnant women for secrecy, there are indications that many sought a measure of confidentiality. What these women most sought, apparently, was protection from the discovery of their situations by their families, and their communities, rather than protection from the discovery of their identities by the adoptive parents and thus by extension by their surrendered children as adults. Agencies often would not serve women who had come from other communities, or would require notification of women's home communities' welfare departments, or would investigate women's parents' financial resources. Therefore, although agency arranged adoptions best facilitated keeping birth and adoptive parents' identities unknown to one another, agencies were frequently urged to make their services more attractive to pregnant women by offering them the kind of secrecy that was available to them in independent adoptions (see Samuels, 2001). These recommendations and the perceptions on which they were based were consistent with the reason uniformly advanced for keeping birth and adoptive parents' identi- 
ties secret-to prevent birth parents from interfering with or harassing adoptive families.

Why then did more than half of the states foreclose adult adoptee access to birth records before 1960 , despite the paucity of specific reasons for such action in professional commentary? One way to address this question is to consider the states' actions in light of the social context in which they occurred. Considering the question in that light, it appears that one factor that may have influenced the passage of these laws was the social attitudes that were developing about the nature of adoption. The legislation may in part have been a reflection of its social context rather than a response to real or imagined problems associated with access to the records. Adoption was increasingly being regarded as a complete and perfect substitute for the creation of families through childbirth. Agencies' practices of matching physical, intellectual, socioeconomic, and other characteristics of adopted children and their adoptive parents embodied "the myth that once the adoption was legalized . . . there would be a 'real' family and the child would be the same 'as if born' to the adopting parents" (Thompson, 1979,p. 13). As a law review article explained with respect to the adopted child's amended birth certificate, it showed "the adoptive parents as the real parents" (Haertle, $1949, \mathrm{p} .43)$. The permanent sealing of all records to all persons may in part have been undertaken as a measure consonant with this understanding of adoption.

This understanding of adoption was fostered by a number of related social attitudes. For example, thinking on child development was increasingly emphasizing the significance of nurture over nature. A 1939 book, noting a former tendency to "stress heredity," enthusiastically advised prospective adoptive parents: "What is done with a child counts more than the circumstances of his birth. He holds possibilities within himself which parental influence and general environment can either develop or crush" (Brooks \& Brooks, 1939, pp. 12, 16). Looking back on the increased popularity of adoption, a 1959 account explains that the demand for children increased when adoptive parents could be assured that "parental morality or immorality was not genetically transmitted, that the adopted child would reflect their behavior and attitudes rather than those of his natural parents" (Zietz, 1959, p. 366).

Another kind of social attitude supporting the developing understanding about adoption was the pervasive emphasis on the traditional family after the dislocations of World War II, what has been termed the "post-war family imperative" (Solinger, 1992, p. 154). The process of adoption, the 1959 account stated, "tends to complete the cultural image 
of the most sanctified and revered of our social institutions-marriage and the family" (Zietz, 1959, pp. 368-69). The executive director of the Child Welfare League in the mid 1950s wrote both that "[i]t can be fairly said that it is not socially acceptable not to have" children (Reid, 1956, p. 136) and that it is extremely difficult, if not impossible, for an unmarried mother to "raise her child successfully in our culture without damage to the child and to herself. ... The concept that the unmarried mother and her child constitute a family is to me unsupportable. There is no family in any real sense of the word" (Reid, 1956, p. 139). Adoption could dissolve the spurious family group and create the authentic one.

Additionally, the developing understanding about adoption was complemented by emerging ideas about the unmarried mother, ideas that were influenced by psychological theories. The white unmarried mother was coming to be seen as mentally ill. As psychologist Anne B. Brodzinsky recounts, "[T] he unplanned pregnancy was understood to be a form of sexual acting out of unconscious needs and as such was seen as an expression of unresolved parent-child conflicts. Furthermore, it was assumed that the pregnancy represented significant psychopathology in the mother" (Brodzinsky, 1990, p. 297). To historian Rickie Solinger, "[T]he cure for the unmarried mother required three steps: remorse; relinquishment of the infant for adoption; and renewed commitment to fulfilling her destiny as a real woman" (Solinger, 1992, p. 95). Total, lifelong separation of the child from the birth mother would surely be seen as consonant with this vision of rehabilitating the unmarried mother and providing the child through adoption with parents mentally equipped to raise the child.

It is also possible that in the same way the law may have reflected social attitudes about adoption, the law in turn may have affected the development of those attitudes. As laws were passed closing court records to all and birth records to all but adult adoptees, the legal regime in which access to identifying information became largely, though not entirely, unlawful may itself have helped foster the idea that lifelong secrecy is an essential feature of adoptions in which the birth and adoptive parents do not know one another. Certainly, negative social meanings came to be attached to the acts of adult adoptees who sought information about their birth families, as evidenced both by professionals' comments and by adoptees' own reports of the social constraints they felt.

Psychiatrist Viola Bernard in 1953 stated that "[I]n emotionally healthy adoptions ... the child's involvement with this biological parents remains within bounds." The provision of some non-identifying details about his parents by understanding parents and agency workers 
may meet an adopted child's "need for connection with his past." But occasionally, she continued, "very disturbed young people who [have] been adopted in early childhood develop an all-consuming, obsessing need to locate their biologic parents who in fantasy, or even delusion, have become the idealized good parents in contrast to the adoptive 'bad' parents with whom they are usually no longer in contact" (Bernard, 1953, pp. 430-31). Historian E. Wayne Carp quotes a 1968 adoption agency manual's characterization of a searching adult adoptee as "a person who 'has had many unhappy past experiences and ... is so intent upon finding the natural parent that he is not able to consider his request in a realistic or rational way." "The caseworker was advised to discourage the search and if necessary to refer the searcher for psychological treatment (Carp, 1998, p. 120). As a legal commentator wrote in 1980, adoptees themselves "felt discouraged from seeking information by the prevailing mood of society at large, by social workers, and by adoptive parents that such interest was unnatural or showed ingratitude" (Harrington, $1980, \mathrm{p} .31$ ). This theme of social disapproval is prominent in two of the autobiographical works widely credited with encouraging the movement for greater openness in adoption, Florence Fisher's The Search for Anna Fisher (Fisher, 1973) and Betty Jean Lifton's Twice Born: Memoirs of an Adopted Daughter (Lifton, 1975).

The existence of widespread and entrenched social attitudes about secrecy in adoption may help explain why the states continued to and were able to continue to close birth records between 1960 and 1990, despite the fact that a social revolution was occurring that challenged both lifelong secrecy and the understanding of adoption as a perfect and complete substitute for creating a family by childbirth. The stigma of illegitimacy lessened and single-parent families became more acceptable, unmarried motherhood was no longer equated with mental illness or an ability to recover easily from surrendering a child, child development thinking shifted back toward more emphasis on the significance of nature, and adoptive families came to be seen as having unique qualities and challenges. Professional literature came to view adoptees' interest in their birth families as normal and perhaps even important to satisfy. A large majority of birth parents were found to be open to or to actually desire contact with adoptees. Adoptees searching for information about or contact with their birth families become familiar figures, no longer assumed to be suffering from mental disorders. Stories about searches and reunions were frequently featured in books, newspapers, magazines, television programs, and movies. A nationwide advocacy movement for greater openness in adoption grew steadily from the $1960 \mathrm{~s}$, and 
mutual aid networks for searching adoptees and birth parents proliferated, expanding in recent years through the Internet (see Samuels, 2001).

As attitudes about secrecy in adoption were threatened by these developments, the states defensively reinforced traditional attitudes by continuing to close records to adult adoptees. Registry schemes did spread throughout the states, under which adoptees and birth parents could seek information or initiate contact once mutual consent was obtained, but these schemes of course presume a baseline arrangement of lifelong secrecy. Traditional attitudes were also defensively constructed by the emergence in court opinions and legal commentary of an ahistorical notion that from the earliest enactments establishing secrecy among the individuals involved in an adoption, a central purpose of the laws was to create a guarantee of or a right to lifelong anonymity for birth parents. In the $1970 \mathrm{~s}$ in the legal literature, no distinction was made between sealing court and birth records to all persons and sealing these records but making an exception for adult adoptee access to birth records. It was as if there had never been periods of time in many states, only recently concluded in some and still ongoing in others, during which adult adoptees had legal access to their birth records. Discourse was phrased in terms of birth parents' guarantees of or rights to anonymity and privacy, both in the articles of legal commentators, including those who favored various degrees of greater openness, and in the opinions of courts in cases in which adoptees sought records access for "good cause" or as a claimed constitutional right (see Samuels, 2001). Officials in a number of states questioned the apparent "inconsistencies" between court record and birth record provisions, ${ }^{5}$ while adoptees in two states reached appellate courts in their efforts to enforce what were plainly stated statutory rights to inspect records upon demand (Florida Dept., 1976; Chambers, 1977).

The persistence of the idea of lifelong secrecy in adoption was evident in the continuing closures of birth records to adult adoptees through most of the past century and by the emergence of a new rationale for secrecy, the permanent protection of birth parents' privacy. Despite the persistence of this idea of lifelong secrecy, the efforts to open birth records to adult adoptees have been gaining significant momentum in recent years. At the time of this writing, due to skillful and persistent efforts of open records advocates, Tennessee, Oregon, and Alabama have re-joined the three states that have always recognized the once universal right of adult adoptees to unrestricted access to information about their origins; Delaware and Nebraska have recognized a right to access 
qualified by the possibility of birth parents' vetoes; seven more states have recognized rights of access prospectively, also subject to birth parents' vetoes; ${ }^{6}$ a handful of states have continued to permit access to or have "reopened" records that were not sealed at the time they were created, ${ }^{7}$ and in at least seven states legislation is pending that would provide greater access. ${ }^{8}$ Perhaps eventually in most states most adult adoptees will again find, as pioneering author Jean Paton found when she went to the Probate Court in 1942: "There was no rigmarole then; you were allowed to see your own paper in a kindly procedure" (Paton, 1968, pp. 51-52).

\section{NOTES}

1. The research described in this column is presented in great detail in an article in the Rutgers Law Review (Samuels, 2001).

2. Arizona, Georgia, Tlinois, Ohio (Samuels, 2001).

3. Connecticut, Louisiana, Massachusetts, Nevada, North Dakota, Wyoming (Samuels, 2001).

4. Alabama, Florida, Idaho, Montana, Oklahoma, Pennsylvania, Utah (Samuels, 2001).

5. E.g., New Hampshire, Oklahoma, Pennsylvania (Samuels, 2001).

6. Colorado, Hawaii, Maryland, Montana, Oklahoma, Vermont, Washington (Samuels, 2001). See generally Hollinger, 2000. 2000.

7. Colorado, Maryland, Ohio, Montana (Samuels, 2001). See generally Hollinger,

8. California, Georgia, Massachusetts, Missouri, New Hampshire, New Jersey, Texas (American Adoption Congress, 2000/2001).

\section{REFERENCES}

Ala. Code $\$ 22-9 \mathrm{~A}-12(\mathrm{c})$.

American Adoption Congress. (2000/2001). Legislative Update. AAC Decree. 18(1) 15.

Bernard, V.W. (1953). Application of Psychoanalytic Concepts to Adoption Agency Practice. In I. E. Smith (Ed.) (1963), Readings in Adoption. New York, NY: Philosophical Library Inc. (Essay first published 1953, reprinted in anthology 1963.)

Brodzinsky, A. B, (1990), Surrendering an Infant for Adoption: The Birthmother Experience. In D. M. Brodzinsky \& M. D. Schechter (Eds.), The Psychology of Adoption (pp. 295-315) Oxford University Press.

Brooks, L. M., \& Brooks, E. C. (1939). Adventuring in Adoption. Chapel Hill, NC: University of North Carolina Press.

Carp, E.W. (1998). Family Matters: Secrecy and Disclosure in the History of Adoption. Cambridge, MA: Harvard University Press.

Chambers v. Parker, 349 So.2d 424 (La. App. 1977). 
Child Welfare League of America (CWLA) (1959). Standards for Adoption Service 1958.

Colby, M. R. (1941). Problems and Procedures in Adoption. Washington, DC: U.S. Department of Labor, Children's Bureau (Publication 262).

Del. Code Ann. Tit. $13 \S 923$ (b).

Fisher, F. (1973). The Search for Anna Fisher. New York, NY: Arthur Fields Books, Inc.

Florida Dept. of Health \& Rehab. Services v. Mullarkey, 340 So.2d 123 (1976).

Goldman, E. (1954). Adoption: New Law, New Problems. Dickerson Law Rev. 59, $57-63$.

Haertle, E. M. (1949). Wisconsin Adoption Law and Procedure. Marquette Law Rev. $33,37-46$.

Harrington, J. D. (1980). The Courts Contend with Sealed Adoption Records. Public Welfare 38, 29-43.

Hollinger, J. H. (2000). State Procedures for Obtaining Identifying Information from Sealed Adoption Records. In J.H. Hollinger et al., Adoption Law and Practice. (pp. 13A1-13A8). New York, NY: Matthew Bender \& Company

Infausto, F. (1969). Annual Review of Decision and Statutory Revisions Affecting Adoptions, Family Law Q. 3, 123- 43.

Lifton, B. J. (1975). Twice Born: Memoirs of an Adopted Daughter. New York, NY: McGraw-Hill Book Company

Morlock, M. (1945). Babies on the Market. Survey Midmonthly 81(3), 67-69.

Morlock, M. (1946). Wanted: A Square Deal for the Baby Born Out of Wedlock. The Child, 10 (11), 167-69 (author a "Consultant in Services for Unmarried Mothers, Social Service Division, U.S. Children's Bureau").

National Conference of Commissioners on Uniform State Laws (NCCUSL) (1942). Uniform Vital Statistics Act. $\$ \S 24,35$.

National Conference of Commissioners on Uniform State Laws (NCCUSL) (1953). Uniform Adoption Act. $\S 13(1), 13(2)$.

National Conference of Commissioners on Uniform State Laws (NCCUSL) (1969). Uniform Adoption Act.

Neb. Rev. Stat. § 43-146.04-.06.

Or. Rev. Stat. $\S 432.240$.

Paton, J. (1968). Orphan Voyage. New York, NY: Vantage Press: (Author published as R.H. Kittson).

Reid, J. H. (1956). Principles, Values, and Assumptions Underlying Adoption Practice. In 1956 National Conference of Social Work, 130-42.

Samuels, E. J. (2001). The Idea of Adoption: An Inquiry into the History of Adult Adoptee Access to Birth Records. Rutgers Law Rev., 53, 367-437.

Solinger, R. (1992). Wake Up Little Suzie: Single Pregnancy and Race Before Roev. Wade. New York, NY: Routledge.

Student comment. (1950). Moppets on the Market: The Problem of Unregulated Adoptions. Yale Law J., 59, 715-36.

Tenn. Code Ann. \$36-1-127.

Thompson, J. (1979). Roots and Rights-A Challenge for Adoption. The Social Worker. 47(1), 13-15.

U.S. Department of Health, Education, \& Welfare, Children's Bureau. (1955). Protecting Children in Adoption, Children's Bureau Publication 354. 
U.S. Department of Health, Education, \& Welfare, Public Health Service, National Office of Vital Statistics. (1959). Model State Vital Statistics Act: 1959 Revision \$ 17(b)(1).

U.S. Department of Health, Education, \& Welfare, Public Health Service, National Office of Vital Statistics. (1960). Digest of Statutory Provisions and Administrative Procedures for Adoption as Related to the Binth Certificate.

Zietz, D. (1959). Child Welfare: Principles and Methods. New York, NY: Wiley.

\section{For FACULTY/PROFESSIONALS with journal subscription} recommendation authority for their institutional library ... .

If you have read a reprint or photocopy of this article, would you like to make sure that your library also subscribes to this journal? If you have the authority to recommend subscriptions to your library, we will send you a free complete (print edition) sample copy for review with your librarian.

1. Fill out the form below and make sure that you type or write out clearly both the name of the journal and your own name and address. Or send your request via e-mail to getinfo@ haworthpressinc.com including in the subject line "Sample Copy Request" and the titte of this journal.

2. Make sure to include your name and complete postal mailing address as well as your institutional/agency library name in the text of your e-mail.

(Please note: we cannot mail specific fournal samples, such as the issue in which a specific article appears. Sample issues are provided with the hope that you might review a possible subscription/e-subscription with your instituiton's fibranan. There is no charge for an institution/campus-wide electronic subscription concurrent with the arctival print edition subscription.]

Q YES! Please send me a complimentary sample of this journal:

(please write complete joumal title here-do not leave blank)

I will show this journal to our institutional or agency library for a possible subscription. Institution/Agency Library:

Name:

Institution:

Address:

City:

State:

Zip:

Return to: Sample Copy Department, The Haworth Press, Inc., 10 Alice Street, Binghamton, NY 13904-1580 